\title{
TRANSFORMASI SOSIAL QUR'ANIK \\ DALAM TAFSIR AL AZHAR
}

\section{Oleh: Ach Jamiluddin ${ }^{1}$}

\begin{abstract}
This research proves that Hamka, in Tafsir Al-Azhar, supports the concept of Transformative Islam by : first reunterprenting Islamic theology with interpretations that makes speculative theoretical debates in islmic theology more applicable to arousing human awareness of their role on earth. Second, it supports islam's alignment with social,economic and political conditions and considers it to be as important as the Godhead in Islam. Third, Formulating islamic transformation action through Ta'muruna bi al ma'ruf, tanhawna 'an al-munkar, and tu'minuna billah, but more emphasis on tu' minuna bil Lah.
\end{abstract}

Keywords: Transformation, Social, Qur'anic, Hamka

Abstrak:Penelitian Ini Membuktikan Bahwa Hamka, dalam Tafsir Al-Azhar, Mendukung Konsep Islam Transformatif dengan Cara; Pertama Menafsirkan Ulang teologi Islam dengan penafsiran yang Membuat perdebatan teoritis spekulatif dalam teologi islam menjadi lebih aplikatif untuk menggugah kesadaran manusia atas peran mereka di muka bumi. Kedua; Mendukung Keberpihakan Islam terhadap kondisi sosial,ekonomi, dan politik dan menganggap itu adalah hal yang sama pentingnya dengan sisi ketuhanan dalam islam. Ketiga; merumuskan aksi transformasi islam lewat Ta'muruna bi al ma'ruf, tanhawna 'an al - munkar, dan tu'minuna billah, namun lebih menekankan kepada tu' minuna bil Lah.

Kata Kunci: Transformasi,Sosial,Qur'anik,Hamka

\section{A. Pendahuluan}

Pada pertengahan Juli 2018, Badan Pusat Statistik (BPS) merilis persentase kemiskinan di Indonesia yang berada pada angka 9,92 persen per Maret 2018. Angka tersebut merupakan terendah sejak tahun $1999 .^{2}$ Dalam catatan BPS, sejak tahun 2011 angka kemiskinan berada pada kisaran 2 digit. Berturut-turut 12,36\% (2011), 11,66\% (2012), 11,46\% (2013), 10,96\% (2014), 11.13\% (2015), 10,70\% (2016), dan 10,12\% (2017).

${ }^{1}$ Ach. Jamiluddin, Alumni Program Doktoral Institut Perguruan Tinggi Ilmu AlQur'an (PTIQ) Jakarta. Email: Ach.jamiluddin@gmail.com

${ }^{2}$ https://ekonomi.kompas.com/read/2018/07/16/130732026/bps-maret-2018persentase-kemiskinan-indonesia-terendah-sejak-1999

47| Ach Jamiluddin 
Meski mengalami penurunan signifikan, data tersebut masih menunjukkan angka signifikan dari mereka yang masih berada dalam taraf kemiskinan. Angka 25,95 juta penduduk memang tergolong sedikit. Tapi dengan kriteria yang paling maksimal tersebut, kita tidak menutup mata pada sebagian besar mereka yang masih tergolong miskin, atau rentan masuk dalam kategori miskin. Menurut Menteri PPN/Kepala Bappenas, Bambang Brodjonegoro, mereka yang rentan miskin berada di angka 69 juta jiwa. ${ }^{3}$

Pada sisi yang lain, indeks pembangunan manusia (IPM) yang mengukur pembangunan manusia dalam tiga bidang: 1) usia hidup, pengetahuan, dan standar hidup layak. Ketiga komponen utama ini dipandang menentukan bagi potensi peningkatan kesejahteraan. Berdasarkan data BPS, usia harapan hidup tahun 2017 meningkat hingga usia 71,06 tahun atau lebih lama 0,16 tahun jika dibandingkan dengan harapan hidup bayi yang lahir pada tahun sebelumnya. Demikian pula dengan harapan lama sekolah pada tahun 2017 menjadi selama 12,85 tahun (Diploma I). Angka itu lebih lama 0,13 tahun bila dibandingkan dengan anak yang berumur sama pada 2016. Sementara itu, pada 2017 masyarakat Indonesia memenuhi kebutuhan hidup dengan rata-rata pengeluaran per kapita sebesar Rp10,66 juta per tahun. Pengeluaran itu meningkat Rp22.000 bila dibandingkan tahun sebelumnya. ${ }^{4}$

Di balik kenyataan tersebut, publik masih diperhadapkan pada diskursus keislaman yang lebih banyak diwarnai perdebatan furu'iyahketimbang ushuliyah. ${ }^{5}$ Perdebatan furu'iyah bersumber dari berbagai pendapat yang berbeda-beda, khususnya dalam tradisi pemikiran fiqh. Perbedaan dalam masalah furuiyah adalah perbedaan yang tidak mendasar dalam Islam. Masing-masing pendapat yang berbeda memiliki argumentasi (dalil) yang

\footnotetext{
${ }^{3}$ https://finance.detik.com/berita-ekonomi-bisnis/d-4052738/69-juta-wni-rentanjadi-orang-miskin

${ }^{4}$ Data Badan Pusat Statistik 2017.

${ }^{5}$ Kaidah Fiqhiyyah Furu'iyah merupakan kaidah-kaidah yang dikategorikan sebagai kaidah yang berada di luar kaidah pokok. Sementara kaidah ini juga sering disebut sebagai kaidah cabang (terjemahan kata far'un) dari kaidah pokok tersebut. Para ulama telah sepakat denganlima kaidah pokok. Kecuali ada ulama yang menambahkannya sehingga jumlahnya menjadi enam buah kaidah. Ibnu Nujaim dari mazhab Hanafi dalam kitabnya Al-Asyabah wa al-Nadhair menyebutkan enam kaidah pokok dengan satu kaidah tambahan yaitu La Tsawaba Illa bi al-Niyat, (tidak ada pahala kecuali dengan niat ). Dalam kitabnya yang dibagi dalam dua pembahasan kaidah yaitu kaidah pokok dan sembilan belas kaidah lainnya. Ibnu Nujaim, Al-Asyabah wa al Nadhair, Damaskus, Daar al Fikr, 1983; Ade Dedi Rohayana, Qawa'id Al Fiqhiyyah dan Pengaruhnya Terhadap Perbedaan Pendapat Fuqaha, Jakarta: PPS UIN Jakarta, 2008, hal 61
} 
menjadi rujukan. Perbedaan antara satu pendapat dengan yang lain, bukan perbedaan antara benar dan salah, akan tetapi perbedaan antara benar dan lebih benar. Sikap terhadap perbedaan furuiyah adalah dengan menerima perbedaan sebagai bagian dari keragaman yang pada hakikatnya adalah sama. Hal yang harus dihindari adalah jangan sampai perbedaan furu'iyah membawa pengaruh pada perpecahan agama. ${ }^{6}$

Perbedaan yang bersifat furuiyah disikapi dengan membenarkan semua yang berbeda, sementara perbedaan ushuliyah perlu ada sikap toleransi yang membiarkan tanpa membenarkan. Bukan sebaliknya, menyikapi perbedaan jenis pertama dengan penuh kebencian dan pertentangan, sebaliknya pada perbedaan jenis kedua seseorang begitu ramah, toleran, dan akomodatif, bahkan kadangkala menyebut semua perbedaan itu adalah sama dan benar. ${ }^{7}$

Di mata dunia, negara-negara Islam masih berkubang dalam persoalan ekonomi dan sosial yang cukup kompleks. Beberapa pekan terakhir, Turki dirundung krisis mata uang yang terjun bebas ke level 6,4323 per dollar Amerika Serikat atau anjlok 15,88 persen. Level tersebut merupakan level terendah dalam masa kepemimpinan Reccep Tayyip Erdogan. Terlepas dari situasi sosial dan politik yang melatarbelakanginya, negara-negara Islam atau berpenduduk muslim tebesar lainnya pun tidak usai dirundung masalah. ${ }^{8}$

Berbagai kondisi di atas terangkum dalam sebuah diskusrsus besar tentang kondisi Islam secara umum dengan warna ketertinggalan, ketergantungan dan ketidakberdayaan yang masih dominan. Menurut Moeslim Abdurrahman, arus besar modernisasi dan idelologi pembangunan telah memaksa umat manusia dalam berbagai sekat agama maupun negara berada dalam sebuah situasi yang tidak semuanya memperoleh keuntungan. Penyebab utamanya adalah modernisasi yang cenderung buta terhadap dampak yang ditimbulkannya. ${ }^{9}$

\footnotetext{
${ }^{6}$ Nur Robi Wahidah, Nasoikhatul Mufida, Anita Roja, dan M. Khoirul Hadi al-Asy ari, "Fiqh Toleransi dalam Perspektif Al-Qur'an Departemen Agama RI", dalam Jurnal Maghza, Vol I, No. 2 Juli-Desember 2016, IAIN Jember 2016.

${ }^{7}$ Nur Robi Wahidah, Nasoikhatul Mufida, Anita Roja, dan M. Khoirul Hadi al-Asy ari, "Fiqh Toleransi....".

${ }^{8}$ https://ekonomi.kompas.com/read/2018/08/20/143108026/krisis-keuangan-turkikehilangan-sepertiga-miliardernya

${ }^{9}$ Moeslim Abdurrahman, Islam Transformatif, Jakarta: Pustaka Firdaus, 1997, hal. 17.
} 


\section{B. Metode Penelitian}

Dalam penelitian ini, ada beberapa langkah penting yang dapat di tempuh. Penelitian ini adalah sebagai pengembangan dari penelitianpenelitian yang terdahulu. Karena itu, penelitian ini merupakan jenis penelitian deskriptif analitik (descriptive research) ${ }^{10}$, yaitu suatu penelitian yang mendeskripsikan data, fakta, dan kecenderungan yang terjadi, yang kemudian dianalisis dan direkomendasikan mengenai apa yang harus dibangun untuk mencapai suatu keadaan. Namun, di lihat dari segi objeknya, penelitian ini termasuk jenis penelitian kepustakaan (library research). ${ }^{11} \mathrm{Di}$ tinjau dari tujuannya, penelitian ini termasuk penelitian eksploratif $^{12}$ sebagai upaya untuk menemukan secara faktual, akurat dan sistematis terhadap fakta dan data tentang konsep transformasi sosial

Berdasarkan jenis penelitiannya, maka pendekatan yang sesuai adalah pendekatan fungsional. Pendekatan fungsional bekerja dengan penekanan pada segi kemanfaatannya bagi masyarakat akademik dan para pelaku pendidikan. Pendekatan fungsionalisme melihat interelasi antara fungsi masyarakat dengan budaya. Dalam konteks penelitian ini, pendekatan fungsionalisme melihat apakah perubahan dan transformasi sosial mendorong lahirnya sebuah pandangan baru. ${ }^{13}$ Pendekatan ini menuntut dilakukan upaya dan langkah untuk mencapai tujuan tersebut.

${ }^{10}$ Descriptive research yakni memusatkan pada gambaran yang akurat dari karakteristik suatu keadaan atau fenomena yang terjadi. Penelitian ini berusaha untuk membuat deskripsi fenomena yang diselidiki dengan cara melukiskan dan mengklasifikasikan fakta dan karakteristik fenomena tersebut secara faktual dan cermat. Jadi penelitian ini digunakan untuk menjawab pertanyaan tentang apa dan bagaimana keadaan sesuatu (fenomena atau kejadian) dan menjelaskan keadaan yang sebenarnya. Dengan demikian, setelah suatu fenomena dideskripsikan, maka jenis penelitian lainnya (korelasional, diferensial, dan kausal) dapat dilakukan. Lihat Burke Johson \& Larry Christensen, Educational Research Quantitative, Qualitative, and Mixed Approaches, Boston: Pearson Education, 2004, hal. 437

${ }^{11}$ Sumardi Suryabrata, Metodologi Penelitian, Jakarta: RajaGrafindo Persada, 2006,Ed.I, h.18. Bahan dan sumber tertulis yang digunakan adalam penelitian yaitu buku, ensiklopedia, jurnal, tesis dan dokumen lainnya yang sesuai dengan prinsip kemutakhiran (recency) dan prinsip relevansi (relevance). Abuddin Nata, Metodologi Studi Islam, Jakarta: RajaGrafindo Persada, 2003, Ed.I, Cet.VIII, hal.125

${ }^{12}$ Muhammad Nazir, Metode Penelitian, Jakarta:Ghalia Indonesia, 1998, hal. 6674

${ }^{13}$ Dalam tatapan fungsionalisme, seorang functionalistviewed culture as a collection of integraetd parts that work together to keep a society functioning. Microsoft Encarta Encyclopedia CD-ROM, 2001, entry "Functionalism". 
Sumber data yang digunakan dalam penelitian ini ada duamacam, yakni sumber primer dan sumber sekunder. Sumber primer adalah buku-buku yang mengkaji pembahasan ini yakni mengenai transformasi sosial, khususnya yang terkait dengan pemikiran keagamaan (sebagai literature review). Selain itu, sumber primer dalam penelitian ini juga diperluas ke sumber-sumber informasi yang terkait langsung dengan topik penelitian termasuk sumber yang diperoleh dari hasil pengamatan dan wawancara. ${ }^{14}$ Tetapi penelitian ini bersifat deskriptif analistis maka hanya digunakan wawancara sebagai bagian dari tujuan penelitian eksploratif.

\section{Paradigma transformatif dalam tafsir al-azhar \\ 1. Melampaui Perdebatan Teologis}

Sebelum dibahas bagaimana Hamka melampaui perdebatan teologis ${ }^{15}$ guna melahirkan Islam yang transformatif, perlu dibahas terlebih dahulu bagaimana hubungan antara perdebatan teologis dalam Islam dengan Islam transformatif dan bagaimana hubungan keduanya bisa dianggap saling menafikan dan juga saling mendukung.

Kenyataannya, agama dengan teologinya tidak akan pernah bisa dipisahkan. Meskipun ada anggapan bahwa ada kenyataan teologi Islam tidak membumi dan tidak memberikan solusi bagi persoalan sosial seperti ketidakadilan, kemiskinan, kebodohan, dan penindasan, tetap saja mengenyahkan teologi dari agama untuk mencapai itu semua bukanlah solusi. Agama tanpa teologi bukanlah agama.

Keringnya teologi Islam dari solusi bagi problem sosial bukan berarti teologi Islam harus dihilangkan, tetapi lebih berarti teologi Islam harus dipahami ulang dan itu tidak harus berarti menawarkan pemahaman baru bagi teologi Islam yang sudah mapan, tetapi bisa juga dengan mengembalikan pemahaman awal teologi Islam yang sudah terkubur di

\footnotetext{
${ }^{14}$ Wawancara (interview) merupakan salah satu bentuk pengumpulan data untuk menghimpun atau memperoleh data yang bisa mencakup fakta, pengetahuan, konsep, pendapat, persepsi atau evaluasi berkenaan dengan fokus masalah yang dikaji dalam penelitian. Jadi tujuan wawancara dilakukan adalah untuk memperoleh informasi guna menjelaskan suatu situasi atau kondisi tertentu, dan untuk melengkapi suatu penyelidikan ilmiah. Lihat Nana Syaodih Sukmadinata, Metode Penelitian Pendidikan, (Bandung: Rosdakarya, 2006), Cet.II, h.216.

${ }^{15}$ Teologi adalah kumpulan ajaran mana saja yang disusun secara koheren menyangkut hakikat Allah dan hubungan-Nya dengan umat manusia dan alam semesta.Lorens Bagus, Kamus Filsafat, Jakarta: Gramedia, 2000, hal. 1090
} 
bawah reruntuhan puing-puing peradaban Islam yang memang sangat besar dan sangat kompleks.

Dalam bukunya, Dari Akidah ke Revolusi, Hassan Hanafi berkata bahwa hubungan manusia dengan Allah tidak hanya sekadar pengetahuan teoritis dan juga spekulatif, melainkan juga pada tataran praktis. Hubungan manusia dengan Allah harus bisa mengenalkan manusia pada tanggung jawabnya terhadap kondisi kontemporer penjajahan, keterbelakangan, pemaksaan, otoritarianisme, kemiskinan, kenestapaan, kesengsaraan, perpecahan, kehinaan, dan kelemahan. Hubungan manusia dengan Allah bukanlah hidup sendiri di pojok rumah ibadah dan melepaskan tanggung jawab dari berbagai persoalan, baik dalam angan-angan maupun dalam kenyataan; melainkan bertanggung jawab untuk mengatasi berbagai problematika dalam kehidupan, menanggulangi malapetaka, mencari sousi bagi berbagai krisis dan bencana. ${ }^{16}$

Cara yang dilakukan Hamka ini dinamai kaum neonormativis oleh Yvonne Y. Haddad, yaitu kaum yang berupaya membangun aturan sosial Islam dalam dunia kontemporer melalui pendekatan al-Quran dalam sebuah cara yang jelas. Tanpa dibebani oleh penafsiran-penafsiran tradisional, historis, linguistik, dan filologis masa lalu. Mereka membiarkan ayat-ayat spesifik diarahkan kepada individu dan masyarakat dalam gerakan eksistensial mereka. Dalam konteks ini, catatan al-Quran menjadi pengesahan dan justifikasi bagi revolusi sebagai Islam yang autentik. Misi umat Islam tidak untuk mengakomodasi petunjuk al-Quran untuk meminjam sistem sosial; bahkan wahyu itu sendiri yang menyediakan ideologi revolusioner untuk mentransformasi dan membebaskan masyarakat dari perbudakan sistem manusia. ${ }^{17}$

Pokok-pokok bahasan teologi Islam adalah: a) analisis konsep tentang Tuhan; b) bukti-bukti ontologis dan kosmologis tentang wujud Tuhan; c) kehendak bebas, determinisme, nasib, kebaikan, keburukan, hukuman dan ganjaran; d) posisi kenabian, sufisme, dan para pewaris nabi; e) hubungan akal dan wahyu; dan f) aspek politik penerapan hukum Ilahi dalam masyarakat. ${ }^{18}$ Kesemua bahasan tersebut tidak mempunyai dampak

\footnotetext{
${ }^{16}$ Hassan Hanafi, Dari Akidah ke Revolusi, (Jakarta: Paramadina, 2003), h. xxi-xxii.

${ }^{17}$ Yvonne Y. Haddad, "the Qur'nic Justification for Islamic Revolution: the View of Sayyid Quthb", dalam Middle East Journal, Vol. 37, No. 1, 1983, hal. 17.

${ }^{18}$ John L. Esposito, Ensiklopedi Oxford Dunia Islam Modern, Jilid 5, Bandung: Mizan, 2002, hal. 14.
} 
langsung dan signifikan bagi kehidupan sosial, ekonomi, dan politik kaum Muslim. Karenanya, kaum Muslim seperti terasing dari dari agamanya sendiri. Teologi sebuah agama adalah hal yang paling mendasar dan hal yang paling mendasar itulah yang tidak memiliki relasi yang kuat dengan kehidupan nyata sehari-hari kaum Muslim. Kecanggihan bahasan tentang pokok-pokok bahasan teologi Islam itu tidak berguna ketika berhadapan dengan kenyataan kemiskinan, ketertindasan, ketidakadilan, serta kebodohan yang adalah kenyataa yang dihadapi oleh kaum Muslim sehari-hari. Bahkan ada dugaan bahwa pokok-pokok bahasan teologi Islam itu malah digunakan oleh pihak-pihak tertentu untuk mengokohkan kekuasaannya atau sebaliknya, merebut kekuasaan dari pihak lain. Keduanya sama-sama menggunakan teologi Islam tidak pada tempatnya.

Kenyataan ketertindasan, kemiskinan, dan keterbelakangan bukanlah takdir yang dihadapannya kaum Muslim harus menyerah atau membiarkan itu terjadi. Kaum Muslim harus mengubahnya dengan cara mengubah diri sendiri lalu mengubah masyarakat yang terkena. Agama saat ini mungkin tidak setuju semua itu terjadi, tetapi agama saat ini juga seperti tidak ada gerakan untuk membuktikan ketidaksetuannya.

Padahal seluruh nabi diutus untuk berjuang melawan penindasan serta mempersatukan mereka yang tertindas dan miskin untuk melawan penindasan dan kemiskinan serta memperjuangkan kesejahteraan mereka. Para nabi pertama-tama mengajak orang-orang untuk meyakini bahwa kebenaran itu ada dan puncak kebenaran itu adalah Allah. Allah yang diyakini adalah Allah Yang Mahaadil dan tempat bergantung segala sesuatu. Karena itu, jika ada ketidakadilan di muka bumi, maka harus dihapuskan tanpa takut kepada siapapun dan kepada apapun karena hanya Allah lah tempat bergantung segala sesuatu.

Setelah itu, para nabi mengajak kaum tertindas untuk percaya kepada kesucian, kesamaan hak dan kewajiban, dan persudaraan kemanusiaan. Karena itu, ketika para nabi dan kaum tertindas itu nantinya mencapai apa yang mereka cita-citakan, tidak akan ada pembalasan dendam atas apa yang mereka dulunya alami karena itu bertentangan dengan kesucian, kesamaan hak dan kewajiban, serta persaudaraan kemanusiaan. Sejarah mencatat bagaimana Nabi Muhammad SAW tetap menghormati orang-orang yang memusuhinya dan mengusirnya dari Makkah saat kaum Muslim menaklukkan kota Makkah. Nabi Musa as diutus untuk memerdekakan Bani 
Israil dari penindasan Firaun. Nabi Isa as diutus untuk memerdekakan masyarakat dari cengkeraman para pemimpin dan para pemuka agama yang menindas.

Agama harus mempunyai jawaban atas problem hidup seperti jutaan orang-orang miskin yang kesulitan keluar dari kemiskinannya, jutaan buruh ditindas, perempuan dilecehkan, anak-anak dieksploitasi, manusia hidup di tempat-tempat kumuh, minioritas etnis ditindas, minoritas agama dicabut hak-hak kemanusiaannya, mayoritas menggencet minoritas, akses pendidikan yang sulit, sedangkan orang-orang kaya menikmati segala fasilitas termasu fasilitas mereka untuk merusak bumi demi kepentingan kekayaan semata.

Ironisnya sekarang, Islam yang pernah jaya dengan peradaban yang penuh kota-kota menakjubkan, kemakmuran material, dan kecanggihan teknik, sekarang berada di dalam kemiskinan yang suram dan keterbelakangan ekonomi yang akut. Seni perniagaan dan wirausaha dihormati dan dipuji dalam agama Islam yang dibawa oleh seorang nabi yang juga adalah seorang pedagang yang sukses, hilang hampir tak berbekas di dalam peradaban Islam masa kini. Ini adalah problem yang harus dipecahkan oleh peradaban Islam. ${ }^{19}$

Pada awal-awal Islam muncul di Makkah hingga menjadi kekuatan besar dan disegani di Madinah, belum begitu tampak adanya perdebatan yang berhadapan antara kekuasaan mutlak Tuhan dengan otonomi manusia atau antara takdir Tuhan dengan kebebasan manusia, apalagi antara Jabariyah dengan Qadariyah. Meskipun demikian, sesungguhnya itu adalah isu yang membayangi setiap agama yang memiliki konsep Tuhan yang personal. Tercatat bahwa tidak hanya Islam yang dihinggapi persoalan serupa, tetapi Kristen pun demikian adanya.

Adapun rekaman Al-Qur'an terhadap perdebatan yang serupa dengan yang tersebut di atas adalah respon Al-Qur'an terhadap konsep kekuasaan mutlak yang sebelumnya ada pada masyarakat di Jazirah Arabia. Pada waktu Islam muncul, pemahaman masyarakat tentang kekuasaan tertinggi yang mampu mengubah dan memengaruhi kehidupan manusia adalah al-dahr, waktu. Itulah yang terekam di dalam QS. al-Jatsiyah/45:24:

${ }^{19}$ Ali A. Allawi, Krisis Peradaban Islam: Antara Kebangkitan dan Keruntuhan Total, terjemahan Pilar Muhammad Mochtar, Bandung: Mizan, 2015, hal. 334. 


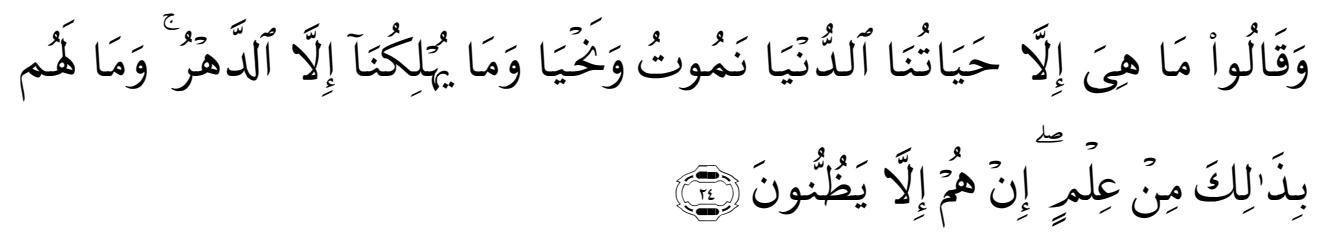

Dan mereka berkata: Tidak ada hidup melainkan kehidupan dunia kita ini, mulanya kita tidak ada, sesudah itu kita hidup, dan tidak ada yang membinasakan kita melainkan masa. Dan tidaklah ada bagi mereka dalam hal yang demikian satu pengetahuan pun. Tidak lain, mereka hanya menyangka-nyangka. (QS. al-Jatsiyah/45:24)

Mereka yang mempunyai pemahaman bahwa kekuasaan tertinggi yang mampu mengubah dan memengaruhi kehidupan manusia adalah aldahr disebut oleh Hamka sebagai "Kaum Dahri". Memang Hamka tidak menyebutkan bahwa itulah pemahaman kekuasaan tertinggi masyarakat Jazirah Arabia sebelum Islam datang. Bahkan Hamka menyamakan Kaum Dahri itu dengan Kaum Materialis dan Kaum Naturalis dan keduanya menganggap Tuhan tidak ada. ${ }^{20}$

Pemahaman Hamka di atas berbeda dengan Dmitri V. Frolov bahwa "Kaum Dahri" bukan menganggap Tuhan tidak ada, tetapi konsep ketuhanan mereka memang tidak menjurus kepada Tuhan yang personal, sebagaimana Islam. ${ }^{21}$ Karena itu, menurut Dmitri V. Frolov, di situlah perbedaan konsep ketuhanan dalam Islam dengan konsep ketuhanan yang saat Islam datang sedang umum dipahami oleh masyarakat Jazirah Arabia.

\section{Islam dan Problem Sosial}

Sebagai rahmatan lî al- âlamîn, Islam mengemban misi mulia karena menjunjung tinggi nilai-nilai keadilan sosial (social justice), persaudaraan universal (universal brotherhood), dan kesetaraan (equality), Hamka adalah salah seorang yang memiliki visi untuk mengembalikan misi mulia Islam itu. Meskipun demikian, Hamka tidak terlepas dari kondisi sosial, ekonomi, dan politik yang melingkupinya. Namun dalam ukuran tertentu, Hamka berhasil menjaga nilai-nilai misi Islam agar tidak ketinggalan zaman.

Di samping perlu untuk memahami mengapa persoalan agama di Indonesia sering dianggap berdiri sendiri terpisah dari persoalan

\footnotetext{
${ }^{20}$ Hamka, Tafsir Al-Azhar, Jilid 9, Singapura: Pustakan Nasional, PTE LTD, 2003, hal. 6618-6619.

${ }^{21}$ Dmitri V. Frolov, "Freedom and Predestination", dalam Jane Dammen McAuliffe (ed.), Encyclopaedia of the Qur'an, Vol. 1, Leiden: Brill 2001, hal. 267.
} 
kesejahteraan masyarakat, keadilan, persamaan derajat, dan ketimpangan sosial, dan kesenjangan ekonomi, perlu ada model pemikiran yang khas AlQur'an dan juga khas Indonesia yang bisa menawarkan sulusi agar kenyataan yang ada menunjukkan bahwa maraknya kehidupan ritual keagamaan di Indonesia bisa berjalan seimbang dengan perkembangan moral dan kehidupan sosial. Hamka, dengan Tafsir Al-Azhar adalah model yang baik untuk hal ini.

Arah pemikiran yang sedang menghendaki untuk berubahnya masyarakat kepada arah yang lebih baik adalah arah pemikiran yang melanda semua disiplin ilmu pengatahuan atau merupakan kritik untuk semua ilmu pengetahuan. Sosiologi dan antropologi yang awalnya hanya dianggap cukup sebagai alat bantu untuk memahami masyarakat dan manusia, mulai pula perlu untuk mempunyai arah agar mengubah masyarakat dan manusia agar menjadi lebih baik.

Ilmu yang awalnya hanya untuk ilmu mulai mendapatkan desakan untuk tidak sekadar untuk ilmu sendiri. Memang jadinya, ilmu menjadi tendesius atau memiliki tendensi di luar dirinya sendiri. Disiplin keilmuan Islam pun mengalami hal serupa, baik teologi, fiqh, maupun tasawufnya. Pertanyaan-pertanyaan seperti: Apa manfaat teologi Islam bagi kehidupan? Jika masyarakat memahami teologi, apa yang mengubah kehidupannya menjadi lebih baik? Jika manusia melaksanakan ritual dengan baik, apakah itu bermanfaat bagi kehidupannya? Bagian mana dari kehidupan yang menjadi lebih baik jika kaum Muslim mendirikan shalat, melaksanakan puasa, menunaikan zakat, dan melaksanakan manasik haji? Memang teologi yang menjadi sasaran utama karena memang dasar agama adalah teologinya, sehingga dengan menggerakkan teologi agar menggerakkan semuanya.

Asghar Ali Engineer menganalisis bahwa ada perbedaan mendasar dalam perjuangan Islam setelah Nabi Muhammad SAW wafat dengan sebelum wafatnya beliau. Pada masa Nabi Muhammad SAW, sama sekali tidak ada kepentingan pribadi yang mencampuri perjuangan cita-cita Islam. Satu-satunya yang menjadi perhatian Nabi Muhammad SAW adalah pembebasan manusia dan kesetaraan kemanusiaan. Setelah Nabi Muhammad SAW wafat, yang terjadi perebutan kekuasaan demi kepentingan pribadi dan golongan.

Kehadiran Islam di Makkah sejak pertama kali bukan semata-mata revolusi teologis karena dari sisi teologi, Islam bukan hal yang asing bagi 
masyarakat Makkah. Penganut agama Kristen dan agama Yahudi di Makkah pasti tidak asing dengan ajaran teologi yang dibawa oleh Nabi Muhammad SAW. Bahkan nama Allah bukan nama yang asing bagi keseluruhan masyarakat Makkah.

Salah satu ayat yang membuktikan tidak asingnya konsep ketuhanan yang dibawa oleh Islam adalah QS. Luqman/31:25:

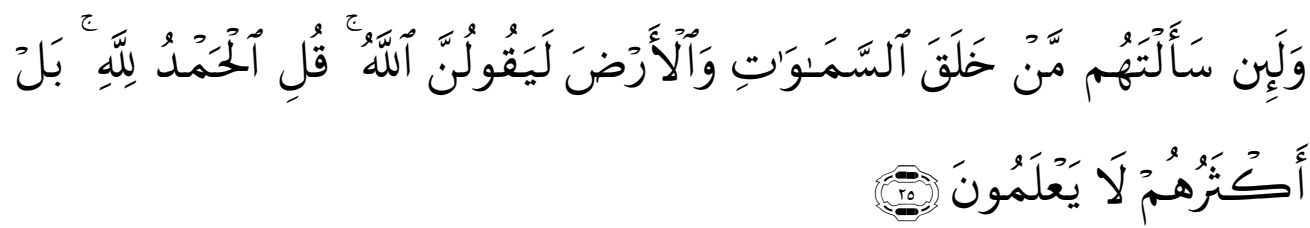

Dan sesungguhnya jika kamu tanyakan kepada mereka: Siapakah yang menciptakan langit dan bumi?" Tentu mereka akan menjawab: "Allah." Katakanlah: "Segala puji bagi Allah." Tetapi kebanyakan mereka tidak mengetahui. (QS. Luqman/31:25).

Menurut Hamka, ayat ini adalah semacam pemberi semangat dan pemberi tanda adanya titik terang dalam dakwah Nabi Muhammad SAW karena umat yang didakwahi bukan umat yang sama sekali tidak tahu tentang apa yang hendak disampaikan oleh Nabi Muhammad SAW dan itu adalah bentuk kemudahan tersendiri bagi dakwah Islam. ${ }^{22}$

Pengetahuan kaum kafir Makkah tentang Allah bisa merupakan pengetahuan yang mereka dapat dari nenek moyang mereka karena itu menjadi pengetahuan umum dan diketahui oleh sipapun dan bisa pula merupakan tanda bahwa siapapun manusia di muka bumi ini pasti akan mengakui di dalam akal mereka yang paling sederhana bahwa pencipta alam raya adalah sebuah kekuatan yang jauh berada di atas alam raya itu sendiri dan mereka menamainya Allah.

\section{Kitab Suci untuk Kaum Tertindas}

Hamka yang mengalami penjajahan pasti memahami dengan baik bagaimana negeri-negeri Muslim dijajah oleh bangsa asing dan memahami bagaimana dampak yang ditimbulkan oleh penjajahan tersebut bagi politik, sosial, dan ekonomi negara-negara yang berpenduduk Muslim, terutama

\footnotetext{
${ }^{22}$ Hamka, Tafsir Al-Azhar, Jilid 7, hal. 5579-5580.
} 
Indonesia. Pengalaman tersebut pasti membekas di dalam sanubari Hamka dan sebuah pertanyaan pastilah muncul: Bagaimana membangkitkan kembali kaum Muslim yang sudah terpuruk?

Tafsir Al-Azhar cukup banyak memberikan gambaran bagaimana membangkitkan kembali kaum Muslim yang terpuruk, namun alam modern yang dianut oleh Hamka membuatnya lebih sering memberikan kritik terhadap diri kaum Muslim sendiri daripada melancarkan kritik kepada yang di luar kaum Muslim. Karena itulah, transformasi Islam sangat cocok bagi pemikiran Hamka.

Tafsir Al-Azhar memang tidak secara gamblang merumuskan bagaimana Islam tranformatif itu, tetapi cara Hamka menuliskan tafsirnya adalah cara yang sang khas transformasi. Untuk melakukan transformasi, masyarakat terlebih dahulu harus memahami pesan-pesan transformasi yang hendak disampaikan. Untuk hal ini, Hamka melakukannya dengan sangat baik lewat Tafsir Al-Azhar karena tafsir ini dituliskan dengan sangat menarik sekaligus sangat membumi karena disertakan contoh-contoh dan perumpamaan-perumpamaan yang sangat khas Indonesia. Dengan cara itu, Hamka seperti mencoba membuat Al-Qur'an itu terasa baru saja turun kepada kaum Muslim Indonesia dan berbicara langsung kepada mereka dengan bahasa mereka sendiri sehingga kaum Muslim terlibat secara psikologis, emosional, dan kondisional dengan pesan-pesan Al-Qur'an itu sendiri. Dengan menghubungkan antara teks-teks Al-Qur'an dengan kenyataan sosial, Hamka seperti mencoba merekonsturksi ulang sebab turunnya Al-Qur'an pada waktu ayat-ayat itu turun kepada kaum Muslim di zaman Nabi Muhammad SAW. Dengan memberikan penjelasan yang sangat akrab dengan kenyataan hidup kaum Muslim Indonesia sehari-hari, Hamka berupaya mengulangi bagaimana Al-Qur'an itu turun pada masa Nabi Muhammad SAW.

\section{Arah Baru Islam Transformatif}

Gagasan Islam Transformatif merupakan respons atas situasi modernitas. Modernisasi yang dipandang mampu menciptakan kehidupan yang lebih baik, justru melahirkan kenestapaan. Terjadi pengotakan tingkat kehidupan, ditambah dengan suasana kapitalisme global yang semakin menyentuh segenap lapisan kehidupan masyarakat. Dunia ketiga bahkan telah mengidentifikasi dunia Islam sebagai bagian di dalamnya. Dalam 
konteks ini, agama diperlukan untuk memberi solusi bagi persoalan keumatan dan kemanusiaa. Pada titik inilah Islam transformatif memiliki relevansinya.

Tansformasi menghendaki agar kaum muslim menciptakan tata sosialmoral yang adil dan egaliter, dalam rangka menghilangkan penyelewengan di atas dunia, fasd fi al- ardl, melalui pertimbangan aspek sosiologis dan ilmu-ilmu sosial. Menghendaki komitmen sebagai makhluk zoon politicon terhadap mereka yang tertindas, untuk bersama-sama mengusahakan pembebasan. ${ }^{23}$ Islam transformatif merupakan pencarian dialogis, yakni agama harus membaca dan memberikan jawaban terhadap ketimpangan sosial. Adapun konsep teologis kritis disodorkan sebagai pendekatan memahami hubungan agama dengan kekuasaan, modernisasi dan keadilan rakyat. Agama pada dasarnya bukanlah identitas sekelompok manusia. Agama diturunkan sebagai hidayah untuk membebaskan manusia dari segala bentuk penghambaan yang melawan nilai-nilai dasar kemanusiaan.

Islam transformatif adalah transformasi kesadaran. Transformasi kesadaran yang dimaksud adalah kesadaran untuk mengubah masyarakat dari kondisinya yang sekarang menuju kepada keadaan lebih dekat dengan tatanan yang ideal. Karena itu dalam kata transformasi di sini, termuat suatu empowering of thepeopleuntuk mengorganisir diri dalam memperbaiki harkat hidup dan martabatnya sebagai manusia yang manusiawi.

\section{E. Penutup}

Gagasan Islam transformatif Hamka dalam Tafsir Al-Azhar adalah:Hamka mendukung keberpihakan Islam terhadap kondisi sosial, ekonomi, dan politik dan menganggap itu adalah hal yang sama pentingnya dengan sisi Ketuhanan dalam Islam. Adapun yang dimaksud dengan keberpihakan Hamka terhadap kondisi sosial, ekonomi, dan politik masyarakat adalah ajaran Islam yang tidak hanya tentang Ketuhanan, tetapi juga tentang kemanusiaan seperti pengayoman terhadap anak yatim, orang miskin, dan budak. Sisi kemanusiaan itulah yang mendapatkan penentangan dari kaum kafir Makkah karena dianggap akan menggoyahkan kekayaan dan kekuasaan mereka.

${ }^{23}$ Budhy Munawar Rahman, Islam Pluralis: Wacana Kesetaraan Kaum Beriman, Jakarta: Paramadina, 2001, hal. 331 


\section{DAFTAR PUSTAKA}

Abdullah,M. Amin,Falsafah Kalam di Era Postmodernisme, Yogyakarta: Pustaka Pelajar, 1995.

Abdurrahman,Asjmuni, Memahami Makna Tekstual, Kontekstual, dan Liberal: Koreksi Pemahaman atas Loncatan Pemikiran, Jakarta: Suara Muhammadiyah, 2009.

Abdurrahman,Moeslim,Islam Sebagai Kritik Sosial, Jakarta: Erlangga, 2003.

Bertens,Kees,Filsafat Barat Abad XX, Yogyakarta: Kanisius, 1991.

Bleicher,Josef,Contemporary Hermeneutics, London: Routledge \& Kegan Paul, 1980.

Bourchier, David, Hadiz Vedi R, Indonesian politics and society: a Reader, Routledge Curzon USA, 1999.

Brenner, Louis (ed.), Muslim Identity and Social Change in Sub-Saharian Africa, 1993.

Brown,Gillian et. al., Discourse Analysis, Cambridge: Cambridge University, 1984.

Cooper, Robert K. dan Ayman Sawaf, Executive EQ: Kecerdasan Emosional dalam Kepemimpinan dan Organisasi, Jakarta: Gramedia Pustaka Utama, 1998.

Data Badan Pusat Statistik 2017.

Departemen Agama RI, Eensiklopedi Islam di Indonesia, Juz, I.Jakarta: Departemen Agama RI, 1993.

Djamal,Murni, DR. H. Abdul Karim Amrullah: Pengaruhnya Dalam Gerakan Pembaruan Islam di Minangkabau pada Awal abad ke-20, Leiden-Jakarta: INIS, 2002.

Esposito,John L,Ensiklopedi Oxford Dunia Islam Modern, Bandung: Mizan, 2002.

,Islam Warna-Warni: Ragam Ekspresi Menuju Jalan Lurus, terjemahan Arif Maftuhin, Jakarta: Paramadina, 1995.

Fakih,Mansour,Masyarakat Sipil untuk Tranformasi Sosial, Yogyakarta: Pustaka Pelajar, 1995.

Hafidhuddin, Didin dan Handri Tanjung, Manajemen Syariah, Jakarta: Gema Insani 2003.

60| Ach Jamiluddin 
Hakim,Ahmad, M. Thalhah, Politik Bermoral Agama, Tafsir Politik Hamka, Yogyakarta: UII Press, 2005.

Ichwan,Moch. Nur,Meretas Kesarjanaan Kritis al-Qur'an: Teori Hermeneutik Nashr Hamid Abu Zayd, Jakata: TERAJU, 2003.

Ife,Jim dkk., Community Development; Alternatif Pengembangan Masyarakat di Era Globalisasi, Yogyakarta: LKis, 2002.

Isa,Kamal Muhammad,Manajemen Pendidikan Islam, Jakarta: Fikahati Aneska, 1994. 
62 | Ach Jamiluddin 